\title{
Effects of presowing gamma irradiation on the photosynthetic pigments, sugar content and carbon gain of Cullen corylifolium (L.) Medik.
}

\author{
Sumira Jan ${ }^{1 *}$, Talat Parween², Rehana Hameed ${ }^{3}$, Tariq O. Siddiqi ${ }^{3}$, and Mahmooduzzafar ${ }^{3}$
}

To determine the effects of gamma radiation on the photosynthetic pigments, sugar content and total carbon gain, seeds of Cullen corylifolium (L.) Medik. were irradiated with variable doses $(0,2.5,5,10,15$, and $20 \mathrm{kGy})$ at the rate of 1.65 $\mathrm{kGy} \mathrm{h}^{-1}$ from ${ }^{60} \mathrm{Co}$ gamma source. Cullen corylifolium represents an important Chinese medicine with adequate levels of secondary metabolites, thus we hypothesized that gamma irradiation could modulate primary metabolites which could supplement secondary metabolite levels. The seeds were then transferred to field for biochemical analysis at different developmental stages; pre-flowering, flowering and post-flowering. Gamma dosage at $10 \mathrm{kGy}$ resulted in a significant increase in concentration of chlorophyll $a(61.17 \%)$, chlorophyll $b(93.18 \%)$ and total chlorophyll $(71.66 \%)$, suggesting that low doses of radiation could activate photosynthetic pigment system while at 15 and $20 \mathrm{kGy}$ dose resulted in depletion of such parameters. Sugar and total C analysis of plants irradiated at $10 \mathrm{kGy}$ demonstrated significantly maximum (216.01\%) sugar content in leaves at all developmental stages and significantly minimum (46.13\%) and (57.81\%) in plants raised from seeds irradiated at 15 and $20 \mathrm{kGy}$ respectively. Effective stimulatory dose for C. corylifolium ' 11062 ' is $10 \mathrm{kGy}$. In contrast, the carotenoid content of the plants exposed to 15 and $20 \mathrm{kGy}$ was maximum than control. Significance of such stimulation correlated with increasing $\mathrm{C}$ mass of the plant concerned is discussed in the light of newer aspects in research.

Key words: Carbon gain, carotenoid, chlorophyll a, chlorophyll b, gamma rays, sugar.

\section{INTRODUCTION}

Gamma rays are imperative in development of mutant varieties and increase of genetic variability (Jan et al., 2011a). Further ever, gamma irradiation has been suggested for quarantine treatment and as valid method of decontamination of medicinal herbs (Variyar et al., 1998; Maity et al., 2009). Gamma rays are known to influence plant growth and development by inducing cytological, genetical, biochemical, physiological and morphogenetic changes in cells and tissues (Gunckel and Sparrow, 1961; Jan et al., 2010). Research on the effects of gamma rays on food sources and animal cells has been done, with little information to date on medicinal plants (Sanada, 1986). Several reports on the stimulatory effects on plant growth using radioactive rays at low doses are available. Such radiation practices, although within range of low doses (5$500 \mathrm{~Gy}$ ) can enhance the physiological activities of cells

\footnotetext{
${ }^{1}$ Kashmir University, Centre of Research for Development (CORD), Naseem Bagh, Srinagar-190006, India.

"Corresponding author (sumira.sam@gmail.com).

${ }^{2}$ Department of Biosciences, Jamia Millia Islamia, New Delhi 110025 , India.

${ }^{3}$ Hamdard University, Department of Botany, New Delhi 110062 , India.

Received: 15 April 2013.

Accepted: 23 October 2013.

doi: $10.4067 / \mathrm{S} 0718-58392013000400003$
}

in plants and photosynthetic microbes by ameliorating germination and growth rates (Thiede et al., 1995; AlSafadi and Simon, 1996; Lee et al., 1998; Thapa, 2004; Puzon, 2005; Melki and Sallami, 2008; Melki and Marouni, 2009; Jan et al., 2010), increase stress resistance (Zaka et al., 2002; Lee et al., 2002a; 2002b; 2003) and/ or improving crop yields (Wiendl et al., 1995; Kim et al., 1998; Al-Safadi et al., 2000). On the erstwhile hand, high dose of gamma ray (2-20 kGy), applied to the seed before sowing, disturbs the protein synthesis (Xiuzher, 1994), results in improper hormone levels (Dwelle, 1975; Rabie et al., 1996), altered enzyme activity (Al-Rumaih and Al-Rumaih, 2008; Vandenhove et al., 2009; Stajner et al., 2009; Jan et al., 2011b), impaired leaf gas and water exchange (Stoeva and Bineva, 2001).

Cullen corylifolium (L.) Medik., a member of Fabaceae family, is significant endangered medicinal plant found in tropical and sub-tropical region of the world (Jain, 1994). The valuable components of this herb are coumarins, psoralen and isopsoralen. Pharmacological tests revealed that they have anti-tumor, anti-oxidative, anti-microbial, anti-inflammatory, anti-mutagenic, and insect hormonal activities (Haraguchi et al., 2002; Khatune et al., 2004; Bapat et al., 2005). In spite of being such an important medicinal plant in Indian and traditional Chinese medicine, there is scarce research documenting the effects of the various environmental stresses on growth, development and metabolism in C. corylifolium. Abiotic 
and biotic stresses cause alterations in the physiological processes of plants and decrease their productivity.

Keeping this background, we used variable doses of gamma rays to study effects of seed irradiation on developing seedlings of $C$. corylifolium. Our objective was to analyze the changes in photosynthetic pigment concentration, $\mathrm{C}$ gain, and sugar content. To do so, we measured and compared photosynthetic pigments, $\mathrm{C}$, and sugar content in control and treated plants at different developmental stages.

\section{MATERIAL AND METHODS}

\section{Procurement of seeds and irradiation}

The seeds of babchi (Cullen corylifolium [L.] Medik.), belong to family Fabaceae, were procured from National Bureau of Plant Genetic Resources (NBPGR), Indian Agricultural Research Institute (IARI), New Delhi, India. Each sample of $25 \mathrm{~g}$ seeds was packed in polythene and were irradiated with different doses of gamma rays $\left(\mathrm{T}_{1}\right.$ : 2.5, $\mathrm{T}_{2}: 5, \mathrm{~T}_{3}: 10, \mathrm{~T}_{4}: 15$, and $\mathrm{T}_{5}: 20 \mathrm{kGy}$ ) at dose rate of $1.65 \mathrm{kGy} \mathrm{h}^{-1}$ (Fricke and Hart, 1996) at room temperature $\left(25 \pm 1{ }^{\circ} \mathrm{C}\right)$ from ${ }^{60} \mathrm{Co}$ gamma irradiator (Gamma chamber GC-5000, BRIT, India) at Institute of Nuclear Medicine and Allied Sciences (INMAS), New Delhi.

Field experiments were repeated three times with 10 replicates. All the seeds were planted in an open atmosphere of Hamdard University, New Delhi (28 $38^{\circ}$ $\mathrm{N}, 77^{\circ} 11^{\prime} \mathrm{E} ; 228 \mathrm{~m}$ a.s.1.), India, about $70-80 \%$ relative humidity, $35{ }^{\circ} \mathrm{C}$ temperature, sandy-loam soil ( $\left.\mathrm{pH} 7.3\right)$. Levels of available $\mathrm{N}$ and $\mathrm{S}$ in soil were 51 and $7.9 \mathrm{mg}$ $\mathrm{kg}^{-1}$, respectively. Seeds were sown the first week of April 2009. Each sample was planted in six rows, $4 \mathrm{~m}$ long and $0.6 \mathrm{~m}$ wide, making an area of $14.4 \mathrm{~m}^{2}$. Hills were $30 \mathrm{~cm}$ apart; five seeds per hill to avoid root disturbance as Cullen plants are very sensitive in the sense that they cannot endure any disturbance of the root. Other agricultural practices such as irrigation and weeding were carried out as required. The planted seeds were observed daily until germination commenced. Dates of commencement and termination of germination as well as the number of seeds that germinated for each day were noted for each of the samples. Leaves from developing seedlings were collected at three developmental stages: pre-flowering (45 d after sowing, DAS), flowering (90 DAS) and postflowering (135 DAS), to analyze the effects of the gamma irradiation on photosynthetic pigment contents, C, and sugar content in control and treated plants.

\section{Soluble sugar content determination}

Soluble sugar was estimated by the method of Dey (1990). Half gram of fresh leaf material was kept in 10 $\mathrm{mL}$ of $90 \%$ ethanol for $1 \mathrm{~h}$ at $60{ }^{\circ} \mathrm{C}$ in incubator. The extract was then decanted into a $25 \mathrm{~mL}$ volumetric flask and the residue was re-extracted. Final volume was made up to $25 \mathrm{~mL}$ by adding $90 \%$ ethanol. An aliquot $(1 \mathrm{~mL})$ was then transferred to a thick walled test tube and $1.0 \mathrm{~mL}$ of $5 \%$ phenol was added and mixed thoroughly and $5 \mathrm{~mL}$ of analytical grade sulfuric acid (97-99\%) was then added and mixed thoroughly by vertical agitation with a glass rod. For exothermic reaction, the test tube was cooled in the air. Absorbance was recorded at $485 \mathrm{~nm}$ on UV-Vis spectrophotometer (model DU 640 Beckman Coulter, Brea, California, USA). The corresponding concentration was determined against a standard curve prepared by using a glucose solution. The amount of sugar was expressed as $\mathrm{mg} \mathrm{g}^{-1}$ fresh weight.

\section{Photosynthetic pigments and carotenoid content}

Total chlorophyll and carotenoid were measured from the fresh leaf by the method of Hiscox and Israelstam (1979).

Extraction. The method involves the estimation of plant pigments without maceration. Leaves, kept on a moist filter paper in an icebox, were washed with cold distilled water. Leaf discs were taken from either side of the midrib at the intraveinal region for the determination of chlorophyll and carotenoid content. Chopped leaf material $(100 \mathrm{mg}$ ) was taken in vials in triplicates containing $7 \mathrm{~mL}$ of dimethyl sulfoxide (DMSO). The vials were then kept in an oven at $65^{\circ} \mathrm{C}$ for $1 \mathrm{~h}$ for complete leaching of the pigments. Thereafter, the volume of DMSO was made up to $10 \mathrm{~mL}$. The chlorophyll content was then measured immediately.

Estimation. A volume of $2 \mathrm{~mL}$ extract was transferred to a cuvette and the absorbance was read at 480, 510, 645 and $663 \mathrm{~nm}$ using a Beckman spectrophotometer (model DU 640, Fullerton, California, USA) against DMSO as a blank. Values of optical densities (ODs) were used to compute the $\mathrm{Chl} a, \mathrm{Chl} b$, total $\mathrm{Chl}$, and carotenoid contents using the following formula:

Chl a $\left(\mathrm{mg} \mathrm{g}^{-1} \mathrm{fw}\right)=\left\{\left[12.3\left(O D_{663}\right)-0.86\left(O D_{645}\right)\right] /(D\right.$

$\times 1000 \times W)\} \times V \quad$ (Maclachlan and Zalik, 1963)

Chl b $\left(\mathrm{mg} \mathrm{g}^{-1} \mathrm{fw}\right)=\left\{\left[19.3\left(\mathrm{OD}_{645}\right)-3.60\left(O D_{663}\right)\right] /(D\right.$

$\times 1000 \times W)\} \times V \quad$ (Duxbury and Yentsch, 1956)

Total Chl $\left(\mathrm{mg} \mathrm{g}^{-1} \mathrm{fw}\right)=\left\{\left[20.2\left(O D_{645}\right)+8.02\left(O D_{663}\right)\right] /\right.$

$(D \times 1000 \times W)\} \times V$ (Arnon, 1949)

Carotenoids $\left(\mathrm{mg} \mathrm{g}^{-1} \mathrm{fw}\right)=\left\{\left[7.6\left(O \mathrm{OD}_{480}\right)-1.49\left(O D_{510}\right) /\right.\right.$

$(D \times 1000 \times W)\} \times V$

(Barnes et al., 1992)

where, $f w$ is fresh weight, $D$ is distance travelled by the light path; $W$ is weight of the leaf material taken; $V$ is volume of the extract; $O D$ is optical density.

\section{Elemental composition and estimation}

Plant parts were analyzed at different samplings for assessing $\mathrm{C}$ status. Five plants were collected from each treatment and were wiped free of any adhering dust. Sampling was first washed in running tap water for $1 \mathrm{~min}$ followed by $1 \mathrm{~min}$ in distilled water. Each sample was dried for $48 \mathrm{~h}$ in hot air oven at $65^{\circ} \mathrm{C}$. Dried samples were fine powdered and passed through a $72 \mathrm{~mm}$ mesh screen. 
The powder was stored in polyethylene bags labeled and used for analysis later.

Carbon content (\% dry weight) was analyzed by packing the known weight of plant sample-powder in tin boats with the help of Elementar System (CHNS Analyse, vario EL, Hanau, Germany).

\section{RESULTS AND DISCUSSION}

Gamma rays belong to ionizing radiation and interact with atoms or molecules to produce free radicals in cells. Photosynthetic pigments can be destroyed by high doses of gamma irradiation, with concomitant loss of photosynthetic capacity (Strid et al., 1990). Photosynthetic apparatus seems to be most sensitive target in plants (Kulandaivelu and Noorudeen, 1983). Gamma irradiation of seeds to improve photosynthesis by modulating pigment system has been reported (Kim et al., 2004; Hegazi and Hamideldin, 2010). The chlorophyll $a$, $\mathrm{Chl} b$, and total chlorophyll content in leaves enhanced significantly $(P<0.05)$ with plant age up to flowering stage and thereafter declined steadily. Chl $a$, Chl $b$, and total chlorophyll increased $61.17 \%, 93.18 \%$, and $71.66 \%$, respectively, with low dose $10 \mathrm{kGy}$ at flowering stage (Tables 1-2-3). Two wheat (Triticum aestivum L.) genotypes ('Roshan' and 'T-65-58-8') raised from seeds irradiated with 100, 200, 300, and 400 Gy exhibited $64.5 \%$ increment in total chlorophyll in both genotypes seedlings that were irradiated at 100 Gy followed by gradual decrease at $200 \mathrm{~Gy}$ dose (Borzouei et al., 2010). The evident rise of chlorophyll concentration in plants exposed to low dose radiation could be a consequence of plant recuperation after exposure. Irradiation of corn seeds increased synthesis of chlorophyll and carotene in seedlings (Vlasyuk and Marina 1970). However, Fan et al. (2003) observed contradictory results since no irradiationinduced increase in chlorophyll or carotenoid was observed probably due to differences in species and/or growing

Table 1. Variation in chlorophyll $a$ content $\left(\mathrm{mg} \mathrm{g}^{-1} \mathrm{fw}\right)$ at various growth stages of Cullen corylifolium exposed to different doses of gamma rays.

\begin{tabular}{lccc}
\hline & \multicolumn{3}{c}{ Developmental stages } \\
\cline { 2 - 4 } Treatments & Pre-flowering & Flowering & Post-flowering \\
\hline Control & $0.73 \mathrm{a} \pm 0.002$ & $0.85 \mathrm{e} \pm 0.005$ & $0.78 \mathrm{~h} \pm 0.029$ \\
$2.5 \mathrm{kGy}$ & $0.86 \pm 0.002$ & $1.07 \pm 0.001$ & $0.97 \pm 0.031$ \\
& $(17.80) \mathrm{b}$ & $(25.88) \mathrm{e}$ & $(24.35) \mathrm{h}$ \\
$5 \mathrm{kGy}$ & $0.98 \pm 0.003$ & $1.21 \pm 0.001$ & $1.08 \pm 0.036$ \\
& $(34.24) \mathrm{c}$ & $(42.35) \mathrm{f}$ & $(38.46) \mathrm{i}$ \\
$10 \mathrm{kGy}$ & $1.07 \pm 0.006$ & $1.37 \pm 0.001$ & $1.28 \pm 0.027$ \\
& $(46.57) \mathrm{d}$ & $(61.17) \mathrm{f}$ & $(64.10) \mathrm{j}$ \\
$15 \mathrm{kGy}$ & $0.63 \pm 0.001$ & $0.74 \pm 0.001$ & $0.70 \pm 0.015$ \\
& $(13.69) \mathrm{d}$ & $(12.94) \mathrm{g}$ & $(10.25) \mathrm{j}$ \\
$20 \mathrm{kGy}$ & $0.39 \pm 0.001$ & $0.53 \pm 0.005$ & $0.51 \pm 0.019$ \\
& $(46.57) \mathrm{d}$ & $(37.64) \mathrm{h}$ & $(34.61) \mathrm{k}$ \\
\hline
\end{tabular}

Values in parenthesis represent percent variation. Values with different letters are significantly different from each other according to Duncan's multiple range test $(\mathrm{P}$ $<0.05)$; values represent mean $\pm \mathrm{SE}(\mathrm{n}=10)$.

Critical difference at P > 0.05: Treatments: 0.019; Developmental stages: 0.014; Treatment developmental stages: 0.044 .
Table 2. Variation in chlorophyll $b$ content $\left(\mathrm{mg} \mathrm{g}^{-1} \mathrm{fw}\right)$ at various growth stages of Cullen corylifolium exposed to different doses of gamma rays.

\begin{tabular}{lccc}
\hline & \multicolumn{3}{c}{ Developmental stages } \\
\cline { 2 - 4 } Treatments & Pre-flowering & Flowering & Post-flowering \\
\hline Control & $0.34 \mathrm{a} \pm 0.008$ & $0.44 \mathrm{ab} \pm 0.007$ & $0.42 \mathrm{~b} \pm 0.002$ \\
$2.5 \mathrm{kGy}$ & $0.40 \pm 0.006$ & $0.55 \pm 0.008$ & $0.48 \pm 0.004$ \\
& $(17.64) \mathrm{a}$ & $(25) \mathrm{b}$ & $(14.28) \mathrm{b}$ \\
$5 \mathrm{kGy}$ & $0.47 \pm 0.013$ & $0.67 \pm 0.008$ & $0.58 \pm 0.013$ \\
& $(38.23) \mathrm{a}$ & $(52.27) \mathrm{b}$ & $(38.09) \mathrm{b}$ \\
$10 \mathrm{kGy}$ & $0.66 \pm 0.011$ & $0.85 \pm 0.011$ & $0.74 \pm 0.013$ \\
& $(94.11) \mathrm{a}$ & $(93.18) \mathrm{b}$ & $(76.19) \mathrm{b}$ \\
$15 \mathrm{kGy}$ & $0.27 \pm 0.012$ & $0.37 \pm 0.010$ & $0.29 \pm 0.008$ \\
& $(20.58) \mathrm{a}$ & $(15.90) \mathrm{b}$ & $(30.92) \mathrm{b}$ \\
$20 \mathrm{kGy}$ & $0.23 \pm 0.013$ & $0.35 \pm 0.020$ & $0.26 \pm 0.474$ \\
& $(32.35) \mathrm{a}$ & $(20.45) \mathrm{b}$ & $(38.09) \mathrm{b}$ \\
\hline
\end{tabular}

Values in parenthesis represent percent variation. Values with different letters are significantly different from each other according to Duncan's multiple range test $(\mathrm{P}$ $<0.05)$; values represent mean $\pm \mathrm{SE}(\mathrm{n}=10)$.

Critical difference at $\mathrm{P}>0.05$ : Treatments: 0.161; Developmental stages: 0.114; Treatment developmental stages: 0.361 .

Table 3. Variation in the total chlorophyll ( $\left.\mathrm{mg} \mathrm{g}^{-1} \mathrm{fw}\right)$ at various growth stages of Cullen corylifolium exposed to different doses of gamma rays.

\begin{tabular}{lccc}
\hline & \multicolumn{3}{c}{ Developmental stages } \\
\cline { 2 - 4 } Treatments & Pre-flowering & Flowering & Post-flowering \\
\hline Control & $1.14 \pm 0.09$ & $1.20 \pm 0.05$ & $1.24 \pm 0.04$ \\
$2.5 \mathrm{kGy}$ & $1.37 \pm 0.15$ & $1.57 \pm 0.03$ & $1.45 \pm 0.13$ \\
& $(20.17) \mathrm{a}$ & $(30.83) \mathrm{b}$ & $(16.93) \mathrm{b}$ \\
$5 \mathrm{kGy}$ & $1.6 \pm 0.15$ & $1.78 \pm 0.04$ & $1.68 \pm 0.11$ \\
& $(40.35) \mathrm{a}$ & $(40.27) \mathrm{b}$ & $(35.48) \mathrm{b}$ \\
$10 \mathrm{kGy}$ & $1.89 \pm 0.15$ & $2.06 \pm 0.11$ & $1.98 \pm 0.11$ \\
& $(65.78) \mathrm{a}$ & $(71.66) \mathrm{b}$ & $(59.67) \mathrm{b}$ \\
$15 \mathrm{kGy}$ & $0.96 \pm 0.07$ & $1.066 \pm 0.02$ & $1.04 \pm 0.06$ \\
& $(15.78) \mathrm{a}$ & $(11.16) \mathrm{b}$ & $(16.12) \mathrm{b}$ \\
$20 \mathrm{kGy}$ & $0.69 \pm 0.09$ & $0.81 \pm 0.01$ & $0.73 \pm 0.08$ \\
& $(39.47) \mathrm{a}$ & $(32.50) \mathrm{b}$ & $(41.12) \mathrm{b}$ \\
\hline
\end{tabular}

Values in parenthesis represent percent variation. Values with different letters are significantly different from each other according to Duncan's multiple range test $(\mathrm{P}$ $<0.05)$; values represent mean $\pm \operatorname{SE}(n=10)$.

Critical difference at $\mathrm{P}>0.05$ : Treatments: 0.141; Developmental stages: 0.124; Treatment developmental stages: 0.381

conditions. Maize (Zea mays L.) dry seeds exposed to gamma doses ranging from 0.1 to $1 \mathrm{kGy}$ exhibited similar biochemical differences based on photosynthetic pigment (Chl $a$, Chl $b$, Car) content displaying an inversely proportional relationship to exposure doses. Furthermore, the concentration of Chl $a$ was higher than $\mathrm{Chl} b$ in both irradiated and non-irradiated seedlings (Marcu et al., 2013a). Similarly lettuce (Lactuca sativa var. capitata) dry seeds exposed to gamma doses ranging from 2-70 Gy indicated that seeds irradiated at doses ranging from 2-30 Gy enhanced the photosynthetic pigments (Chl $a$, Chl $b$, Car) content, while at higher doses (70 Gy) resulted in decline of the assimilatory pigments (Marcu et al., 2013b).

Carotenoid pigment plays an important role in radiation damage and free radical scavenging (Fukuzawa et al., 1998). Age and dose dependent significant $(P<$ 0.05 ) increase was observed in Car content in leaves of C. corylifolium being maximum at pre-flowering $(75 \%)$ at $10 \mathrm{kGy}$ followed by flowering $(68.08 \%)$ and postflowering $(59.61 \%)$ stages (Table 4). However, Kim et al. (2004) contradicted this statement by proposing that, 
Table 4. Variation in carotenoid content $\left(\mathrm{mg} \mathrm{g}^{-1} \mathrm{fw}\right)$ at various growth stages of Cullen corylifolium exposed to different doses of gamma rays.

\begin{tabular}{lccc}
\hline & \multicolumn{3}{c}{ Developmental stages } \\
\cline { 2 - 4 } Treatments & Pre-flowering & Flowering & Post-flowering \\
\hline Control & $0.441 \mathrm{a} \pm 0.015$ & $0.471 \mathrm{e} \pm 0.013$ & $0.523 \mathrm{i} \pm 0.001$ \\
$2.5 \mathrm{kGy}$ & $0.552 \pm 0.007$ & $0.565 \pm 0.013$ & $0.657 \pm 0.001$ \\
& $(25) \mathrm{b}$ & $(19.14) \mathrm{f}$ & $(25.62) \mathrm{ij}$ \\
$5 \mathrm{kGy}$ & $0.703 \pm 0.023$ & $0.680 \pm 0.008$ & $0.745 \pm 0.001$ \\
& $(59.09) \mathrm{bc}$ & $(44.68) \mathrm{fg}$ & $(42.30) \mathrm{j}$ \\
$10 \mathrm{kGy}$ & $0.771 \pm 0.013$ & $0.790 \pm 0.014$ & $0.837 \pm 0.002$ \\
& $(75) \mathrm{c}$ & $(68.08) \mathrm{g}$ & $(59.61) \mathrm{k}$ \\
$15 \mathrm{kGy}$ & $0.337 \pm 0.013$ & $0.369 \mathrm{~h} \pm 0.009$ & $0.393 \pm 0.004$ \\
& $(25) \mathrm{d}$ & $(23.40) \mathrm{h}$ & $(25) \mathrm{kl}$ \\
$20 \mathrm{kGy}$ & $0.223 \pm 0.015$ & $0.196 \pm 0.006$ & $0.2471 \pm 0.002$ \\
& $(50) \mathrm{de}$ & $(59.57) \mathrm{h}$ & $(53.84) \mathrm{l}$ \\
\hline
\end{tabular}

Values in parenthesis represent percent variation. Values with different letters are significantly $(\mathrm{P}<0.05)$ different from each other (Duncan's multiple range test).

Values represent mean $\pm \operatorname{SE}(n=10)$.

Critical difference at $\mathrm{P}>0.05$ : Treatments: 0.0159; Developmental stages: 0.0112 ; Treatment developmental stages: 0.0355 .

chlorophylls are practically insensitive to low dosage gamma irradiation whereas the levels of carotenoid increase in a dosage dependent manner at the same degree of irradiation. Furthermore, plants adapt to environment more widely through high photon energy use efficiency by increasing the proportion of $\mathrm{Chl} b$ in reaction centers involved in photosynthesis. These findings are consistent with our results showing positive correlation with growth attributes of $C$. corylifolium, considering the fact that plant biomass and nitrogen content was also increased at flowering following low doses gamma rays (Jan, 2011).

The sugar content of leaves enhanced significantly $(P$ $<0.05)$ with plant age being maximum $(216.01 \%)$ at 10 $\mathrm{kGy}$ dose of gamma irradiation while minimum (57.81\%) with $20 \mathrm{kGy}$ at pre-flowering stage (Table 5). Such a decline in sugar content at post-flowering stage following higher gamma dosage is correlated with observed suppression in pigments. Increased soluble sugar content at flowering stage may be associated with increased photosynthetic activity. Sucrose content of both potato (Solanum tuberosum L.) tubers and sweet potato roots

Table 5. Variation in sugar content $\left(\mathrm{mg} \mathrm{g}^{-1} \mathrm{fw}\right)$ at various growth stages of Cullen corylifolium exposed to different doses of gamma rays.

\begin{tabular}{lccc}
\hline & \multicolumn{3}{c}{ Developmental stages } \\
\cline { 2 - 4 } Treatments & Pre-flowering & Flowering & Post-flowering \\
\hline Control & $2.56 \mathrm{a} \pm 0.06$ & $3.49 \pm 0.062$ & $2.76 \mathrm{~g} \pm 0.01$ \\
$2.5 \mathrm{kGy}$ & $3.40 \mathrm{~b} \pm 0.03$ & $4.56 \pm 0.08$ & $3.96 \pm 0.02$ \\
& $(32.81) \mathrm{b}$ & $(30.65) \mathrm{m}$ & $(43.47) \mathrm{h}$ \\
$5 \mathrm{kGy}$ & $5.61 \pm 0.02$ & $6.81 \mathrm{n} \pm 0.04$ & $6.17 \pm 0.01$ \\
& $(119.1) \mathrm{c}$ & $(95.12) \mathrm{n}$ & $(123.55) \mathrm{i}$ \\
$10 \mathrm{kGy}$ & $8.09 \pm 0.01$ & $9.04 \pm 0.003$ & $8.64 \pm 0.06$ \\
& $(216.01) \mathrm{d}$ & $(159.02) \mathrm{o}$ & $(213.04) \mathrm{i}$ \\
$15 \mathrm{kGy}$ & $1.47 \pm 0.02$ & $1.88 \pm 0.01$ & $1.78 \pm 0.04$ \\
& $(42.57) \mathrm{e}$ & $(46.13) \mathrm{p}$ & $(35.50) \mathrm{j}$ \\
$20 \mathrm{kGy}$ & $1.08 \pm 0.002$ & $1.62 \pm 0.02$ & $1.33 \pm 0.01$ \\
& $(57.81) \mathrm{f}$ & $(53.58) \mathrm{q}$ & $(51.81) \mathrm{k}$ \\
\hline
\end{tabular}

Values in parenthesis represent percent variation. Values with different letters are significantly different from each other according to Duncan's multiple range test $(\mathrm{P}$ $<0.05)$; values represent mean $\pm \operatorname{SE}(n=10)$.

Critical difference at $\mathrm{P}>0.05$ : Treatments: 0.044; Developmental stages: 0.031; Treatment developmental stages: 0.099 . was increased at irradiation dose of 3 to $4 \mathrm{kGy}$ and 0.8 to $2 \mathrm{kGy}$, respectively (Ezekiel et al., 2007). Further, free sugar, glucose, sucrose, and maltose were significantly increased by 7.5 and $10 \mathrm{kGy}$ gamma irradiation in fruits (Byun et al., 1997). The increase in sugar content supports some changes in grain starch granules which have been reported earlier (Błaszczak et al., 2002; Gralik and Warchalewski, 2006), where ionizing radiation caused visible changes in the microstructure of kernel starchy-endosperm at $10 \mathrm{kGy}$. Increment and decrease in soluble sugar content following low and high gamma doses respectively has been reported in Eruca vesicaria subsp. sativa (Moussa, 2006). The decrease in sugar contents of plants under maturation stage can be due to two factors, the leaf senescence induced by the gamma radiation, because the reserves as $\mathrm{N}$ compounds and sugars are transported to the sink. Other explanation is the photosynthetic reduction through stomatal closure and consequent lower entrance of $\mathrm{CO}_{2}$ in leaf tissue, as well as degradation of photosynthetic pigments promoted by oxidative stress during irradiation (Jan et al., 2011b).

Maximum increase in root $(72.23 \%)$, stem $(40.57 \%)$ and leaf $\mathrm{C}(69.92 \%)$ was recorded with $10 \mathrm{kGy}$ at flowering stage where as maximum decline of root $(18.84 \%)$, stem $(21.49 \%)$ and leaf C (34.17\%) was recorded with $20 \mathrm{kGy}$ (Figure 1). Carbon content in root and aerial parts of $C$. corylifolium plants was recorded highest during flowering stage following low doses of gamma rays but declined thereafter. This decline coincided with plants irradiated with 15 and $20 \mathrm{kGy}$. The maximum $\mathrm{N}$ content was recorded in stem and minimum in roots at post-flowering stage. Results of our experiment indicate that the photosynthesis and sugar content was increased in plants raised from seeds irradiated with low doses of gamma rays. These results were almost in agreement with those of Cailian et al. (1993); El-Sayed et al. (1994); Al-Kobaisi et al. (1997); Gautam et al. (1998); Rascio et al. (2001) and Osama (2002), who have reported the improvement

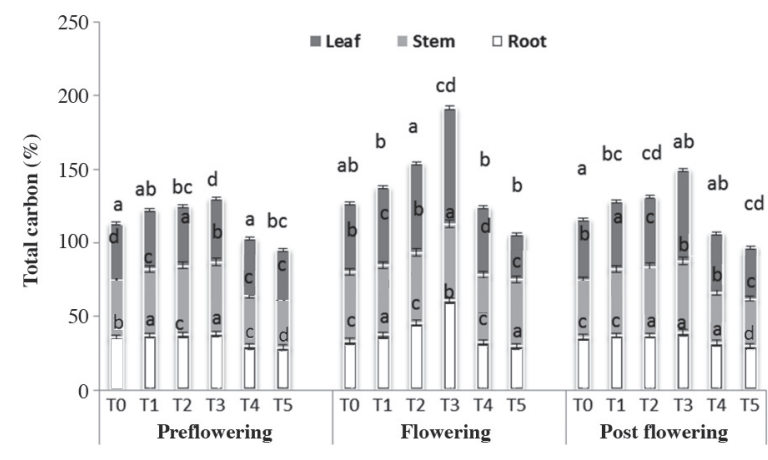

Bars represents the mean $\pm \mathrm{SE}(\mathrm{n}=10)$. Values with different letters are significantly different from each other according to Duncan's multiple range test $(\mathrm{P}<0.05) . \mathrm{T}_{1}: 2.5, \mathrm{~T}_{2}: 5, \mathrm{~T}_{3}: 10, \mathrm{~T}_{4}: 15$ and $\mathrm{T}_{5}: 20 \mathrm{kGy}$.

Figure 1. Variation in total $\mathrm{C}(\%)$ content per $\mathrm{mg}$ at various developmental stages of Cullen corylifolium exposed to different doses of gamma rays. 
of yield components and C containing compounds (chlorophyll parameters and carotenoid) in various plants such as tomato, maize, rice and wheat following gamma irradiation. Reduced C gain was also supported by Ursino et al. (1974), who found that photosynthesis was reduced by half in Pinus strobes exposed to 10 Gy. Higher doses of gamma rays were not lethal and they caused very little visual damage to the plants. Presence of significant differences between total biomass would suggest change in the rate of fixed C. Our study exhibited that radiation resulted in decrease in leaf area at higher doses of gamma rays, while showing negative relationship to photosynthesis and a strong positive relationship to leaf density. Similar results have been observed in sunflower plants exposed to variable doses of gamma rays (Thiede et al., 1995).

\section{CONCLUSION}

Our results presented above are concerned with persistence of changes prevalent from seed to seed cycle, where the inhibition in photosynthetic, accessory pigments, sugar content and $\mathrm{C}$ mass were more prevalent over doses of 15 and $20 \mathrm{kGy}$. Low doses of ionizing radiations have modulatory role in the metabolic and biochemical processes of seedling. Effective stimulatory dose for plant development is $10 \mathrm{kGy}$ for Cullen corylifolium, while the dosage of $20 \mathrm{kGy}$ can prove detrimental for the concerned plant.

\section{LITERATURE CITED}

Al-Kobaisi, N.M., I.F. Ibrahim, A.A. Kraibat, and A.K. Kadhem. 1997. Induced mutations for leaf rust and lodging resistance in wheat Triticum aestivum L. Crop Improvement 24:256-258.

Al-Rumaih, M.M., and M.M. Al-Rumaih. 2008. Influence of ionizing radiation on antioxidant enzymes in three species of Trigonella. American Journal of Environmental Sciences 4:151-156.

Al-Safadi, B., Z. Ayyoubi, and D. Jawdat. 2000. The effect of gamma irradiation on potato microtuber production in vitro. Plant Cell Tissue Organ Culture 61:183-187.

Al-Safadi, B., and P.W. Simon. 1996. Gamma irradiation induced variation in carrots (Daucus carota L.) Journal of American Society of Horticultural Science 121:599-603.

Arnon, D.I. 1949. Copper enzyme in isolated chloroplast polyphenol oxidase in Beta vulgaris L. Plant Physiology 24:1-15.

Bapat, K., G.J. Chintalwar, U. Pandey, V.S. Thakur, H.D. Sarma, and G. Samuel. 2005. Preparation and in vitro evaluation of radio iodinated bakuchiol as an antitumour agent. Applied Radiation Isotopes 62:389-393.

Barnes, J.D., I. Balaguer, E. Manrique, S. Elvira, and A.W. Davison. 1992. A reappraisal of the use of DMSO for the extraction and determination of chlorophylls $a$ and $b$ in Lichens and higher plants. Environment and Experimental Botany 32:85-100.

Błaszczak, W., J. Gralik, E. Klockiewicz-Kamińska, J. Fornal, and J.R. Warchalewski. 2002. Effect of $\gamma$-radiation and microwave heating on endosperm microstructure in relation to some technological properties of wheat grain. Food Nahrung 46:122129. doi:10.1002/1521-3803(20020301).

Borzouei, A., M. Kafi, H. Khazaei, B. Naseriyan, and A. Majdabad. 2010. Effects of $\gamma$ radiation on germination and physiological aspects of wheat (Triticum aestivum L.) seedlings. Pakistan Journal of Botany 42:2281-2290.
Byun, M.W., H.S. Yook, O.J. Kwon, and I.J. Kang. 1997. Effects of gamma irradiation on physicochemical properties of Korean red ginseng powder. Radiation Physics and Chemistry 49:483-489.

Cailian, W., S. Mei, G. Xu, and Z. Kongnan. 1993. Mutagenic effects of sup1Sup7 Cs gamma rays and sodium azide combined treatment on rice (Oryza sativa L.) Journal of Nuclear Agricultural Sciences 1:21-28.

Dey, P.M. 1990. Methods in plant biochemistry. Vol. II. Carbohydrates. Academic Press, London, UK.

Duxbury, A.C., and C.S. Yentsch. 1956. Plant and pigment monography. Journal of Air Pollution and Control Assessment $16: 145-150$.

Dwelle, R.B. 1975. Abscission of Phaseolus and Impatiens explants: Effects of ionizing radiations upon endogenous growth regulators and in de novo enzyme synthesis. Plant Physiology 56:529-534.

El-Sayed, H.H., F.M. Abd El-Tawab, A. El-Souedy, M.T. Sharabash, and A.M. Asmahan. 1994. Effects of gamma irradiation on growth, yield and chemical constituents for three tomato varieties and their crosses. Second Arab Conference on the Peaceful Uses Energy, Cairo. 5-9 November. Arab Atomic Energy Agency (AAEA), Atomic Energy Authority, Cairo, Egypt.

Ezekiel, R., G. Rana, N. Singh, and S. Singh. 2007. Physicochemical, thermal and pasting properties of starch separated from -irradiated and stored products. Food Chemistry 105:1420-1429.

Fan, X., K.T. Rajkowski, and D.W. Thayer. 2003. Quality of alfalfa sprouts grown from irradiated seeds. Journal of Food Quality 26:165-176.

Fricke, H., and E. Hart. 1996. Chemical dosimetry. In Attix, F.H., and. W.C. Roesch (eds.) Radiation dosimetry. Vol. 2. Academic Press, New York, USA

Fukuzawa, K., Y. Inokami, J. Terao, and A. Suzuki. 1998. Rate constants for quenching singlet oxygen and activities for inhibiting lipid peroxidation of carotenoids and $\alpha$-tocopherol in liposomes. Lipids 3:751-756.

Gautam, R.K., G.S. Sethi, M.K. Rana, and S.K. Shama. 1998. Induction inheritance pattern and agronomic performance of awned mutants in multiple disease resistant bread wheat cultivar. Indian Journal of Genetic and Plant Breeding 58:417-422.

Gralik, J., and J.R. Warchalewski. 2006. The influence of gammairradiation on some biological activities and electrophoresis patterns of wheat grain albumin fraction. Food Chemistry 99:289298.

Gunckel, J.E., and A.E. Sparrow. 1961. Ionizing radiation: Biochemical, physiological and morphological aspects of their effects on plants. p. 555-583. In Ruhland, W. (ed.) External factors affecting growth and development. Encyclopedia of plant physiology. Springer, Berlin, Germany.

Haraguchi, H., J. Inonui, Y. Tamura, and K. Mizutani. 2002. Antioxidative components of Psoralea corylifolia L. (Leguminosae). Phytotherapeutic Research 16:535-544.

Hegazi, A.Z., and N. Hamideldin. 2010. The effect of gamma irradiation on enhancement of growth and seed yield of okra [Abelmoschus esculentus (L.) Moench] and associated molecular changes. Journal of Horticulture and Forestry 2(3):38-51.

Hiscox, J.D., and G.F. Israelstam. 1979. A method for extraction of chlorophyll from leaf tissue maceration. Canadian Journal of Botany 57:1332-1334.

Jain, S.K. 1994. Ethnobotany and research on medicinal plants in India. Ciba Foundation Symposium 185:153-168.

Jan, S. 2011. Developmental and metabolic changes in Psoralea corylifolia $\mathrm{L}$. with reference to ionising radiation. $\mathrm{PhD}$ thesis (Awarded). Hamdard University, Department of Botany, Jamia Hamdard, New Delhi, India.

Jan, S., T. Parween, T.O. Siddiqi, and Mahmooduzzafar. 2010. Gamma radiation effects on growth and yield attributes of Psoralea corylifolia $\mathrm{L}$. with reference to enhanced production of psoralen. Plant Growth Regulation 64:163-171.

Jan, S., T. Parween, T.O. Siddiqi, and Mahmooduzzafar. 2011a. Effect of gamma radiation on morphological, biochemical, and physiological aspects of plants and plant products. Environmental Reviews 20:17-39. 
Jan, S., T. Parween, T.O. Siddiqi, and Mahmooduzzafar. 2011b. Anti-oxidant modulation in response to gamma radiation induced oxidative stress in developing seedlings of Psoralea corylifolia L. Journal of Environmental Radioactivity 113:142-149.

Khatune, N.A., M.E. Islam, M.E. Haque, P. Khondkar, and M.M. Rahman. 2004. Antibacterial compounds from the seeds of Psoralea corylifolia L. Fitoterapia 75:228-230.

Kim, J.H., M.H. Baek, B.Y. Chung, S.G. Wi, and J.S. Kim. 2004. Alterations in the photosynthesis pigments and antioxidant machineries of red pepper (Capsicum аппиит L.) seedlings from gamma-irradiated seeds. Journal of Plant Biotechnology 47:314 321

Kim, J.S., J.K. Kim, Y.K. Lee, M.W. Baek, and J.G. Kim. 1998 Effects of low dose gamma radiation on the germination and yield components of Chinese cabbage. Korean Journal of Environment and Agriculture 17:274-278.

Kulandaivelu, G., and A.M. Noorudeen. 1983. Comparative study of the action of ultraviolet-C and ultraviolet- B on photosynthetic electron transport. Physiologia Plantarum 58:389-394.

Lee, H.Y., J.S. Kim, M.H. Baek, Y.K. Lee, and D.S. Im. 2002a. Effects of low dose $\gamma$-radiation on the growth, activities of enzymes and photosynthetic activities of gourd (Lagenaria siceraria). Korean Journal of Environmental Biology 20:197-204.

Lee, H.Y., J.S. Kim, M.H. Baek, S.C. Park, and Y.I. Park. 2002b. Effects of low dose $\gamma$-radiation on photosynthesis of red pepper (Capsicum annuum L.) and the reduction of photoinhibition. Korean Journal of Environment and Agriculture 21:83-89.

Lee, H.Y., J.S. Kim, M.H. Baek, J.C. Yoo, and S.T. Kwon. 2003. Effects of low dose gamma irradiation on physiological activities of radish (Raphanus sativus) during early growth and reduction of gamma stress. Journal of Korean Society of Horticultural Science 44:314-320.

Lee, E.K., J.S. Kim, Y.K. Lee, and Y.B. Lee. 1998. Effect of low dose $\gamma$-irradiation on the germination and growth in red pepper (Capsicum annuum L.) Journal of Korean Society of Horticultural Science 39:670-675.

Maclachlan, S., and S. Zalik. 1963. Plastid structure, chlorophyll concentration, and free amino acid composition of a chlorophyll mutant of barley. Canadian Journal of Botany 41:1053-1062.

Maity, J.P., S. Kar, S. Banerjee, A. Chakraborty, and S.C. Santra. 2009. Effects of gamma irradiation on long-storage seeds of Oryza sativa (cv. 2233) and their surface infecting fungal diversity. Radiation Physics and Chemistry 78:1006-1010.

Marcu, D., V. Cristea, and L. Daraban. 2013b. Dose-dependent effects of gamma radiation on lettuce (Lactuca sativa var. capitata) seedlings. International Journal of Radiation Biology 89:219-223.

Marcu, D., G. Damian, C. Cosma, and V. Cristea. 2013a. Gamma radiation effects on seed germination, growth and pigment content, and ESR study of induced free radicals in maize (Zea mays). Journal of Biological Physics 39:625-634

Melki, M., and A. Marouni. 2009. Effects of gamma rays irradiation on seeds germination and growth of hard wheat. Environment Chemistry Letters 12:1531-1534.

Melki, M., and D.H. Sallami. 2008. Studies the effects of low dose of gamma rays on the behaviour of chickpea under various conditions. Pakistan Journal of Biological Sciences 11:2326-2330.

Moussa, R.H. 2006. Gamma irradiation regulation of nitrate level in rocket (Eruca vesicaria subsp. sativa) plants. Journal of New Seed 8:91-101.

Osama, M.S. 2002. Molecular genetic studies on irradiated wheat plants. PhD. Thesis of Genetic. Ain Shams University, Faculty of Agriculture, Shubra Alkhaima, Cairo, Egypt.
Puzon, K.A.M. 2005. Mathematical analysis of root growth in gamma-irradiated cashew (Anacardium occidentale L.) and mangosteen (Garcinia mangostana L.) using fractals. Nature and Science 3:59-64.

Rabie, K.A.E., S.A.M. Shehata, and M.A. Bandok. 1996. Hormone imbalance, germination, growth and pod shedding of Faba beans as affected by gamma irradiation. Annals of Agricultural Science 41:551-556.

Rascio, A., M. Russo, L. Mazzucco, C. Platani, G. Nicastro, and N. Di Fonzo. 2001. Enhanced osmotolerance of wheat mutant selected for potassium accumulation. Plant Science 160:441-448.

Sanada, T. 1986. Induced mutation breeding in fruit trees resistant mutant to black spot disease of Japanese pear. Gamma Field Symposium 25(4):87-108

Stajner, D., B.M. Popovic, and K. Taski. 2009. Effects of $\gamma$-irradiation on antioxidant activity in soybean seeds. Central European Journal of Biology 4:381-386.

Stoeva, N., and T.Z. Bineva. 2001. Physiological response of beans (Phaseolus vulgaris L.) to gamma-irradiation treatment I. Growth, photosynthesis rate and contents of plastid pigments. Journal of Environmental Protection and Ecology 2:299-303.

Strid, A., W.S. Chow, and J.M. Anderson. 1990. Effects of supplementary gamma irradiation on photosynthesis in Pisum sativum. Biochemistry 1020:260-268.

Thapa, C.B. 2004. Effect of acute exposure of gamma rays on seed germination and seedling growth of Pinus kesiya Gord and $P$. wallichiana A.B. Jacks. Our Nature 2:13-17.

Thiede, M.E., S.O. Link, R.J. Fellows, and P.A. Beedlow. 1995 Effects of gamma radiation on stem diameter growth, carbon gain and biomass partitioning in Helianthus annuus. Environment and Experimental Botany 35:33-41.

Ursino, D.J., A. Moss, and J. Stimac. 1974. Changes in the rates of apparent photosynthesis in $21 \%$ and $1 \%$ oxygen and of dark respiration following a single exposure of three-year-old Pinus strobus L. plants to gamma radiation. Radiation Botany 14:117125 .

Vandenhove, H., N. Vanhoudt, J. Wannijn, M. Van Hees, and A Cuypers. 2009. Effect of low-dose chronic gamma exposure on growth and oxidative stress related responses in Arabidopsis thaliana. Radioprotection 44:5487-5491.

Variyar, P., C. Bandyopadhyay, and P. Thomas. 1998. Effect of gamma irradiation on the phenolic acids of some Indian spices. International Journal of Food Science and Technology 33:533537.

Vlasyuk, P.A., and V.V. Marina. 1970. The effect of seed irradiation on the biochemistry of corn plants under different nutrient conditions. Physiology Biochemistry of Cultivated Plants 2:468472 .

Wiendl, F.M., F.W. Wiendl, J.A. Wiendl, A. Vedovatto, and V. Arthur. 1995. Increase of onion yield through low dose of gamma irradiation of its seeds. Radiation Physics and Chemistry 46:793795.

Xiuzher, L. 1994. Effect of irradiation on protein content of wheat crop. Journal of Nuclear and Agricultural Science 15:53-55.

Zaka, R., C. Chenal, and M.T. Misset. 2002. Effect of low doses of ionizing radiation on antioxidant enzymes and $\mathrm{G}_{6} \mathrm{PDH}$ activities in Stipa capillata (Poaceae). Journal of Experimental Botany 53:1979-1987. 